\title{
Effect of partial replacement of cement by ground granulated blast furnace slag and sand by iron ore tailings on properties of concrete
}

\author{
Ravikiran Kattoli ${ }^{1^{*}}$, Brijbhushan. $\mathrm{S}^{2}$, Maneeth.P. $\mathrm{D}^{2}$, Shreenivas Reddy. $\mathrm{S}^{3}$ and Siddharth. $\mathbf{B}^{2}$ \\ PG Student, Department of Construction Technology, VTU CPGS, Karnataka, India ${ }^{1}$ \\ Assistant Professor, Department of Construction Technology, VTU CPGS, Karnataka, India ${ }^{2}$ \\ Professor, Department of Construction Technology, VTU CPGS, Karnataka, India ${ }^{3}$
}

\section{(O2018 ACCENTS}

\begin{abstract}
Iron ore tailings (IOT) are the mining waste left after extraction of iron ore. The particles of IOT have grain size of sand and since there is a problem of disposal it can be used as an ingredient in concrete. Ground granulated blast furnace slag (GGBFS) is a waste obtained from blast furnace. Since it has fineness similar to cement, it can be used as an ingredient in concrete. In the present experimental investigation, natural sand is partially replaced by IOT at $(10 \%, 20 \%, 30 \%$ and 40\%) different percentages. The cement part was substituted with different percentages of the GGBFS (5\%, 10\%, $15 \%$, and 20\%). Tests on fresh concrete and hardened properties were conducted. Slump cone test and compaction factor test was carried out to find the workability of concrete. Compressive strength test, split tensile strength test, flexural strength test and durability test was conducted to find the strength of concrete. Superplasticizer (SP) was added to have good workability for all replacement levels. The concrete with $20 \%$ IOT and 10\% GGBFS achieved more split tensile (3.86 $\left.\mathrm{N} / \mathrm{mm}^{2}\right)$, compressive strength $\left(53.47 \mathrm{~N} / \mathrm{mm}^{2}\right)$ and flexural strength $\left(7.33 \mathrm{~N} / \mathrm{mm}^{2}\right)$ than normal concrete. In the durability test of cube specimen, as the substitution \% of the concrete mixture increases, the water absorption rate increases. Mix design is carried out for M40 grade concrete.
\end{abstract}

\section{Keywords}

Iron ore tailings, Ground granulated blast furnace slag, Superplasticizer and durability.

\section{Introduction}

Concrete is widely used building material with cement, fine aggregate (FA), coarse aggregate (CA) and water. It has a wide range of structural applications. The ingredients of the concrete must be rightly proportioned to have good workability, high strength and durability.

In the construction industry, the demand for Iron and Steel is increasing day by day. There are many iron ore mining companies being established due to the presence of ample reserve of iron ore in India. After mining process, the waste generated in the form of IOT is about 10 to 12 million tonnes per annum in India [1]. Another waste produced from iron industry is GGBFS.

IOT are the waste left after extracting valuables from the uneconomic portion of the ore. Tailings contain fine-grained particle sizes ranging from sand grain size to a few microns usually in the form of slurry of a mixture of mineral particles and water.

*Author for correspondence

269
The disposal of IOT was a major burden to the mining industries. Environmental friendly and sustainable disposal methods have to be chosen by the industries concerned.

At present, the IOT are stored in the tailings dam or stockpiled closer to the mining sites. Some of the mining companies use chosen by the industries concerned for land reclamation and as backfill to previously mined-out areas [2].

GGBFS is a glassy granulated fine powder acquired by quenching slag of molten iron from a blast furnace in water or steam. In blast furnace iron ore, coke and limestone are subjected from the top of the furnace, while hot air is driven from the lower part of the furnace moving by a sequence of pipes so that when the material falls, a chemical reaction takes place down the entire furnace. The by-products obtained were slag phases and molten iron with slag floating above the molten iron. The molten iron is tapped off and the molten slag is subjected to quenching. Fragments obtained were ground to have fineness similar to cement [3]. 


\subsection{Scope of the work}

In order to conserve the natural sand and reduce the cost needed for FA in concrete production, IOT waste generated after ore extraction process is used as a substitute to FA. In many parts of the country, as Steel production plant increases in number, the waste generation is likely to increase. So instead of disposing and causing problem to environment, we can effectively use as a replacement to sand. The IOT material has fine particles of the size of a grain of sand to a few micrometres.

In order to reduce the environmental problem as there is emission of carbon dioxide to atmosphere in the cement production process, GGBFS which is a waste produced from blast furnace is used as an alternative to cement. GGBFS has inherent cementing properties.

\subsection{Objectives}

The objectives of the study are:

1. Replacement of FA by IOT and cement by GGBFS.

2. To determine the properties of IOT and ground GGBFS.

3. To find the workability of concrete for different percentage replacement of IOT and GGBFS.

4. To determine the workability of concrete with the addition of SP for different percentage replacement of IOT and GGBFS.

5. To determine the strength properties of concrete for different percentage replacement of IOT and GGBFS with the addition of superplasticizer.

\section{Literature review}

The resistance to attack in aggressive environments is due to presence of mineral composition of GGBFS. Cement can't be replaced completely. Even if it is replaced partially it gives good results and sustainable construction [3].

FA is substituted partially at $10 \%, 20 \%, 30 \%, 40 \%$ and $50 \%$ by IOT. It was seen that as the replacement $\%$ increases, workability of mix reduces. Replacement at $40 \%$ IOT gave max compression strength than Conventional concrete (C.C) and all other \%replacement. The flexural strength was more for reference mix than the IOT substituted mixes [4]. Studied on split tensile and compression strength due to use of IOT as a replacement to FA on road pavements. The split tensile and compression strength was maximum at $40 \%$ IOT replacement. The strength starts reducing after $50 \%$ IOT replacement [1].
Experimental study was carried for $\mathbf{M}_{20}$ grade concrete replacing sand by IOT at $10 \%, 20 \%, 30 \%$, $40 \%, 60 \%, 80 \%$, and $100 \%$. The max increase in compressive strength occurs for $40 \%$ sand replacement. Flexural strength of the reinforced concrete beam is found to be maximum for $40 \%$ sand replacement [5].

Cement was substituted by GGBFS at 10\%, 20\%, $30 \%$ and $40 \%$. Fosroc conplast SP was used which had a dosage range of 0.5 to 2 liters per $100 \mathrm{~kg}$ cement. The dosage was constant for all mixes that is $1.8 \%$ by weight of cement. The concrete mixture having $30 \%$ GGBFS achieved the highest compression split tensile and flexural strength with all variations in comparison to conventional concrete mixture [6].

The superplasticizers used in concrete were AUROMIX 400, AUROMIX200, BASF and BUILDPLAST. Using all the superplasticizers caused a remarkable reduction in the requirement of cement content from $425 \mathrm{~kg} / \mathrm{m}^{3}$ (concrete without admixture) to $360 \mathrm{~kg} / \mathrm{m} 3$ in concretes with admixtures. There was an improvement in workability. There was 10 to $15 \%$ increase in Compressive strength. There was 20 to $25 \%$ increase in flexure strength. The water absorption and permeability are reduced by about 50\% [7].

Studied the properties of M25grade concrete when cement was replaced by GGBFS and natural sand by marble slurry waste. At $40 \%$ marble slurry and $20 \%$ GGBFS in concrete mix the slump increased and it was also found that the compression, split tensile and flexure strength was more than target strength of M25 grade concrete [8].

Concrete mix with cement replacement by GGBFS will be economical and environmentally sustainable option as it can reduce the emission of carbon dioxide. When cement was replaced partially by GGBFS at $30 \%$ there was $13.13 \%$ increase in compressive strength and $6.97 \%$ increase in flexural strength [9].

Studied on concrete properties, when cement was replaced partially at $30 \%, 40 \%$ and $50 \%$ by GGBFS. The dosage of SP was $0.7 \%$ by weight of cement for all mix. Based on strength properties the most optimized mix was at $30 \%$ GGBFS. Beyond $40 \%$ replacement the strength decreases [10]. 
3.Experimental investigation

\subsection{Materials}

\subsubsection{Cement}

The cement used is ordinary Portland cement 53 grade confirming to IS $12269-1987$. It was procured from a single source. Various tests are conducted on cement to check the properties of cement [11]. The properties of cement are listed in Table 1.

\subsubsection{Ground granulated blast furnace slag}

It was obtained from JSW cement limited, Vijayanagar works, Bellary. Figure 1 shows the ground granulated blast furnace slag. Table 1 shows the physical properties of cement tested in the laboratory. Table 2 shows the physical properties of ground granulated blast furnace slag.

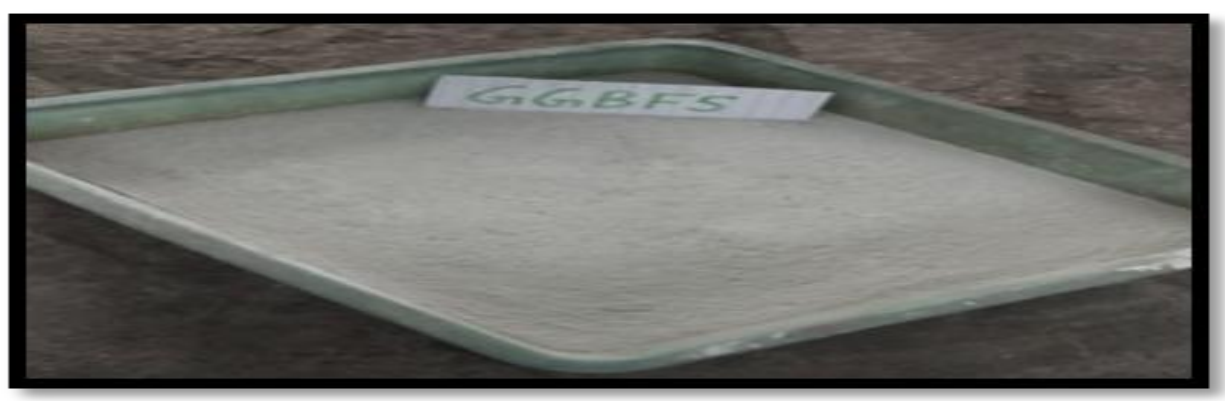

Figure 1 Ground granulated blast furnace slag

Table 1 Physical properties of cement tested in the laboratory

\begin{tabular}{lll}
\hline S. No & Property & Result \\
\hline 1 & Specific gravity & 3.10 \\
2 & Standard consistency & $32 \%$ \\
3 & Initial setting time & $50 \mathrm{~min}$ \\
4 & Final setting time & 270 \\
5 & Fineness & $5 \%$ \\
6 & Soundness & $2 \mathrm{~mm}$ \\
\hline
\end{tabular}

Table 2 Physical properties of ground granulated blast furnace slag

\begin{tabular}{lll}
\hline S. No & Characteristics & Result \\
\hline 1 & Colour & off white \\
2 & Fineness $\left(\mathrm{M}^{2} / \mathrm{kg}\right)$ & 382 \\
3 & Specific gravity & 2.88 \\
4 & 45 Micron (Residue) $(\%)$ & 7.4 \\
\hline
\end{tabular}

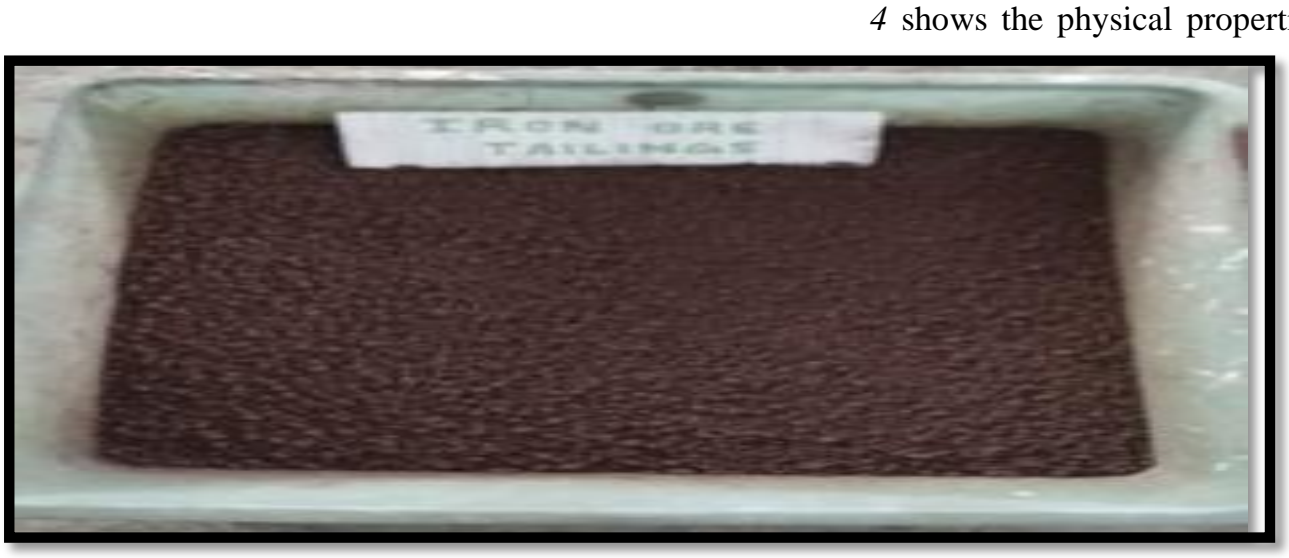

Figure 2 Iron ore tailings

271

\subsubsection{Fine aggregate}

Natural river sand (from Shahapur) is used. Various Tests are carried on Sand to find the properties as per IS: 2386 (part-2). The sand used was dry and free from vegetation [12]. Refer Table 3 for results.

Table 3 Results on fine aggregate

\begin{tabular}{lll}
\hline S. No & Properties & Results \\
\hline 1 & Specific gravity & 2.71 \\
2 & Fineness modulus & 2.94 \\
3 & Water absorption & $1.93 \%$ \\
4 & Silt content & Nil \\
5 & Bulk density (loose condition) & $1.8 \mathrm{~g} / \mathrm{cc}$ \\
6 & Bulk density (dry condition) & $1.97 \mathrm{~g} / \mathrm{cc}$ \\
7 & Moisture content & Nil \\
\hline
\end{tabular}

\subsubsection{Iron ore tailings}

It was obtained from Kej minerals, Toranagal village in Sandur Taluk of Bellary district (Figure 2). Table 4 shows the physical properties of iron ore tailings. 
Kattoli et al.

Table 4 Physical properties of iron ore tailings

\begin{tabular}{lll}
\hline S. No & Characteristic & Value \\
\hline 1 & Specific gravity & 2.66 \\
2 & Colour & reddish brown \\
3 & Water absorption & $15.87 \%$ \\
4 & Fineness modulus & 3.78 \\
5 & Optimum moisture content & $8.84 \%$ \\
6 & Maximum dry density & $2.508 \mathrm{~g} / \mathrm{cc}$ \\
\hline
\end{tabular}

\subsubsection{Coarse aggregate}

The gravel obtained from local quarries is used as CA. The maximum size of $\mathrm{CA}$ is $20 \mathrm{~mm}$. The performance of $\mathrm{CA}$ is found by testing according to IS 2386 (Part 3) [13]. 40:60 proportion of $20 \mathrm{~mm}$ and $10 \mathrm{~mm}$ fraction by mass of $\mathrm{CA}$ is finalized for casting. Table 5 shows the physical properties of coarse aggregate.

Table 5 Physical properties of coarse aggregate

\begin{tabular}{lll}
\hline S. no & Properties & Values \\
\hline 1 & Specific gravity & 2.81 \\
2 & Fineness modulus & 7.01 \\
3 & Water absorption & 1.10 \\
4 & Shape of coarse aggregate & Angular \\
5 & Bulk density (loose condition) & $1.40 \mathrm{~g} / \mathrm{cc}$ \\
6 & Bulk density (dry condition) & $1.59 \mathrm{~g} / \mathrm{cc}$ \\
7 & Moisture content & $16.10 \%$ \\
8 & Crushing test & $17.40 \%$ \\
\hline
\end{tabular}

\subsubsection{Water}

According to IS: 456-2000, for all works on concrete, potable water without excess salt is used [14].

3.1.7Superplasticizer (Conplast SP430)

SP used in the present investigation is Fosroc conplastSP430.The dosage of SP for different replacement percentages of IOT and GGBFS in concrete is found by conducting trials on slump test.

\subsection{Mix proportion}

Mix proportion for M-40 grade concrete per metre cube after correction for water absorption [15] (Table $6)$.

Table 6 Mix proportion

\begin{tabular}{llll}
\hline Cement & FA & CA & Water \\
\hline 1 & 1.487 & 2.648 & 0.508 \\
$437.7 \mathrm{Kg}$ & $650.97 \mathrm{Kg}$ & $1159.07 \mathrm{Kg}$ & $222.7 \mathrm{Kg}$ \\
\hline
\end{tabular}

\subsection{Mixing and casting}

First sand, CA and cement (for replacement material IOT and GGBFS are added at different percentages) are mixed in dry condition for one minute, and then water is added (SP is added for replacement materials along with water) and thoroughly mixed to get a uniform mix. The mixing should be done within 3 to 5 minutes. For cubes, concrete is cast in cubical 272 moulds of size $15 \mathrm{~cm} \times 15 \mathrm{~cm} \times 15 \mathrm{~cm}$. For a cylinder, moulds with $15 \mathrm{~cm}$ diameter and $30 \mathrm{~cm}$ height are used. For prism, a mould of size $50 \mathrm{~cm}$ length, $10 \mathrm{~cm}$ width and $10 \mathrm{~cm}$ depth is used.

\subsection{Curing}

For curing specimen were immersed in water. It was demolded after $24 \mathrm{hrs}$. The specimens are cured for a specified time.

\subsection{Experimental tests}

3.5.1Tests on fresh concrete

The tests on fresh concrete are performed to measure the concrete workability. Slump and compaction factor test are carried out in our experiment for C.C, MX1 (10\%IOT, 5\%GGBFS), MX2 (20\%IOT, 10\%GGBFS), MX3 (30\% IOT, 15\% GGBFS) and MX4 (40\% IOT, 20\% GGBFS).

$$
\begin{aligned}
& \text { slump } \\
& =\text { Height after removal of slump cone } \\
& \text { - Height before removal of slump cone } \\
& \text { compaction factor } \\
& =\frac{\text { weight of partially compacted concrete }}{\text { weight of fully compacted concrete }}
\end{aligned}
$$

3.5.2Tests on hardened concrete

Compression split tensile, flexure and durability test were performed. \% IOT and GGBFS replacement are given as M1A (10\%IOT, 5\%GGBFS + .15\%S.P), M2B (20\%IOT, 10\%GGBFS+0.5\%S.P), M3C (30\%IOT, $15 \%$ GGBFS+1\%S.P), M4D (40\%IOT, $20 \% \mathrm{GGBFS}+1.5 \%$ S.P) and normal concrete mix (C.C) [16].

3.5.2.1Compressive strength test

Compressive strength of concrete depends on w/c ratio, quality of materials used, strength of cement and quality control (Figure 3). Test is carried on compression testing machine (CTM). Loading is controlled through central valve at $14 \mathrm{~N} / \mathrm{mm}^{2} / \mathrm{min}$

$$
\text { Compressive strength }=\frac{\text { load at failure }}{\text { area of specimen }}
$$

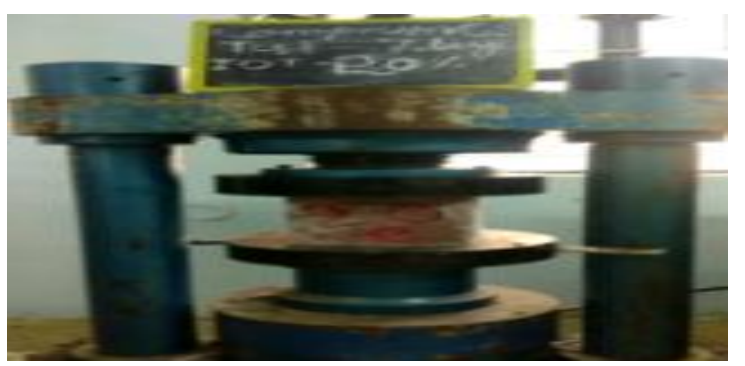

Figure 3 Cube subjected to compression test under CTM 
3.5.2.2Split tensile strength

It is tested under CTM with two steel plates placed at the top and bottom of specimen (Figure 4). Load is applied at the rate of 1.4 to $2.1 \mathrm{~N} / \mathrm{mm}^{2} / \mathrm{min}$.

Split tensile strength, Tsp $=\frac{2 \times \mathrm{P}}{\pi \times \mathrm{d} \times \mathrm{l}}$

$\mathrm{P} \rightarrow$ Applied load, $\mathrm{d} \rightarrow$ diameter

$1 \rightarrow$ length of specimen

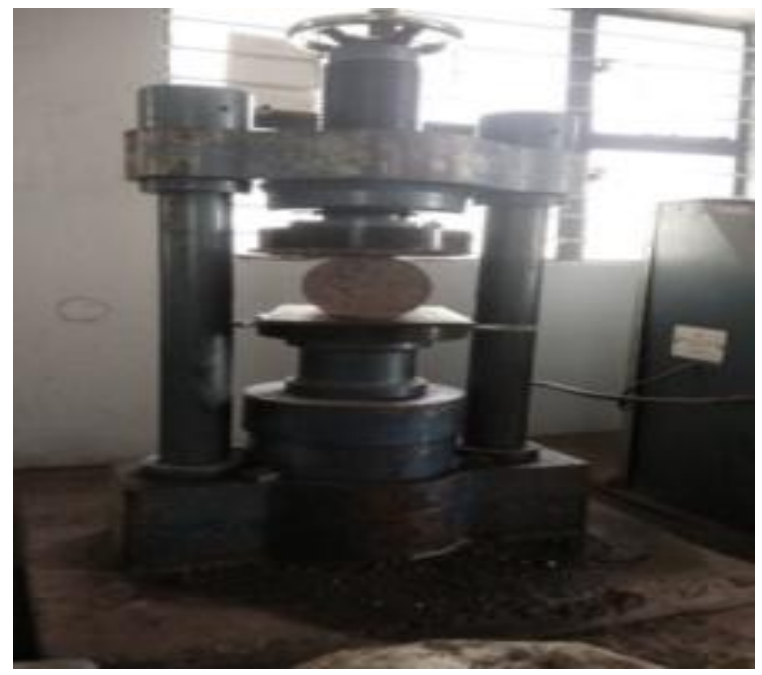

Figure 4 Tensile strength test of cylinder

\subsubsection{Flexural strength test}

Test can be conducted either by three point loading method or single point loading method. In our project the test is carried on three point loading method. Figure 5 shows the prism subjected to third point loading method load is applied continuously till the point of failure.

Flexural strength, $\mathrm{fbt}=\frac{\mathrm{P} \times \mathrm{l}}{\mathrm{b} \times \mathrm{d}^{2}}$

$\mathrm{P} \rightarrow$ Load at failure, $\mathrm{l} \rightarrow$ support span, $\mathrm{b} \rightarrow$ width, $\mathrm{d} \rightarrow$ depth

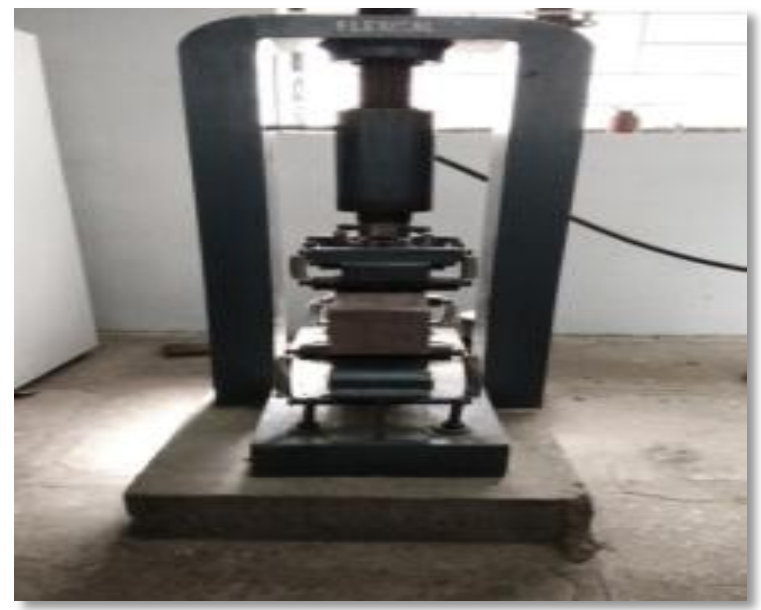

Figure 5 Prism subjected to third point loading method

\subsubsection{Durability test}

Water absorption test is carried out to find durability of concrete. If there are more voids then there will be more absorption of water decreasing the durability. Oven and weighing balance are required to carry out the experiment. This test is carried after 56 days curing of cube specimen.

water absorption $(\%)=\frac{(\mathrm{W} 2-\mathrm{W} 1)}{\mathrm{W} 1} \times 100$

$\mathrm{W} 1 \rightarrow$ Oven dried weight of specimen

$\mathrm{W} 2 \rightarrow$ specimen wet weight after immersion in water

\section{Results and discussion}

\subsection{Results on fresh properties}

Initially the slump test was carried without using any superplasticizer to check the workability of concrete. Based on the test conducted the values of slump cone test and compaction factor test are indicated the table. Table 7 shows the slump value obtained without superplasticizer. The dosage of superplasticizer and slump value for all replacement level (Table 8).

Table 7 Slump value obtained without superplasticizer

\begin{tabular}{lll}
\hline S. no & Mix type & Slump value in mm \\
\hline 1 & C.C & 105 \\
2 & MX1 (10\%IOT,5\%GGBFS) & 95 \\
3 & MX2 (20\%IOT,10\%GGBFS) & 26 \\
4 & MX3 (30\%IOT,15\%GGBFS) & 0 \\
5 & MX4 (40\%IOT,20\%GGBFS) & 0 \\
\hline
\end{tabular}

Table 8 Dosage of superplasticizer and slump value for all replacement level

\begin{tabular}{llll}
\hline S. no & Mix type & Dosage of SP $(\%)$ & Slump value in mm \\
\hline 1 & MX1 (10\%IOT,5\%GGBFS) & 0.15 & 102 \\
2 & MX2 (20\%IOT,10\%GGBFS) & 0.5 & 65 \\
3 & MX3 (30\%IOT,15\%GGBFS) & 1.0 & 75 \\
4 & MX4 (40\%IOT,20\%GGBFS) & 1.5 & 55 \\
\hline
\end{tabular}


Kattoli et al.

As the values of slump obtained for all replacement levels have good workability. Hence the dosages fixed are now incorporated to all the further tests. Table 9 shows the results of compaction factor test.

Table 9 Results of compaction factor test

\begin{tabular}{lll}
\hline S. no & Mix type & Compaction factor \\
\hline 1 & C.C & 0.95 \\
2 & M1A & 0.92 \\
3 & M2B & 0.9 \\
4 & M3C & 0.91 \\
5 & M4D & 0.88 \\
\hline
\end{tabular}

As the replacement level increases the compaction factor value decreases. This indicates the fall in the level of workability.

\subsection{Results on hardened properties}

A total of 45 cubes, 45 cylinders and 45 prisms were casted. For each value 3 moulds were casted and test was performed. The average of the three values was taken for each result.

Table 10 shows that the compressive strength was maximum $\left(53.47 \mathrm{~N} / \mathrm{mm}^{2}\right)$ for the mix M2B (20\% IOT and $10 \%$ GGBFS) than the conventional concrete $\left(51.40 \mathrm{~N} / \mathrm{mm}^{2}\right)$.
Table 11 shows that the split tensile strength was maximum $\left(3.86 \mathrm{~N} / \mathrm{mm}^{2}\right)$ for the mix M2B $(20 \%$ IOT and $10 \%$ GGBFS) than the conventional concrete $\left(3.53 \mathrm{~N} / \mathrm{mm}^{2}\right)$.

Table 12 shows that the split tensile strength was maximum $\left(7.33 \mathrm{~N} / \mathrm{mm}^{2}\right)$ for the mix M2B $(20 \%$ IOT and $10 \%$ GGBFS) than the conventional concrete $\left(7.16 \mathrm{~N} / \mathrm{mm}^{2}\right)$.

In the durability test, the water absorption rate increases as the replacement level increases in the concrete mixture. The water absorption is maximum for mix M4D (40\% IOT and 20\% GGBFS) that is $0.86 \%$ (Table 13).

Table 10 Results of compression test

\begin{tabular}{lllll}
\hline S. no & Mix type & \multicolumn{3}{c}{ Compressive } \\
& & 3dtrength $\left(\mathbf{N} / \mathbf{m m}^{2}\right)$ & 7days & 28days \\
\hline 1 & C.C & 18.81 & 32.29 & 51.40 \\
2 & M1A & 17.32 & 31.55 & 49.74 \\
3 & M2B & 21.0 & 33.75 & 53.47 \\
4 & M3C & 16.73 & 27.70 & 41.77 \\
5 & M4D & 14.36 & 24.13 & 31.8 \\
\hline
\end{tabular}

Table 11 Results of split tensile test

\begin{tabular}{llll}
\hline S. No & Mix type & \multicolumn{2}{c}{ Split tensile strength $\left(\mathbf{N} / \mathbf{m m}^{\mathbf{2}}\right)$} \\
\hline 1 & & $\mathbf{7 d a y s}$ & $\mathbf{2 8 d a y s}$ \\
2 & C.C & 2.63 & 3.53 \\
3 & M1A & 2.44 & 3.34 \\
4 & M2B & 2.68 & 3.86 \\
5 & M3C & 1.88 & 3.02 \\
\hline
\end{tabular}

Table 12 Test results of flexural strength

\begin{tabular}{llrc}
\hline S. no & Mix type & \multicolumn{2}{c}{ Flexural strength $\mathbf{( N / \mathbf { m m } ^ { 2 } )}$} \\
\cline { 3 - 4 } & & 7days & $\mathbf{2 8 d a y s}$ \\
\hline 1 & C.C & 5.33 & 7.16 \\
2 & M1A & 4.66 & 6.83 \\
3 & M2B & 5.66 & 7.33 \\
4 & M3C & 4.33 & 6.83 \\
5 & M4D & 3.83 & 6.66 \\
\hline
\end{tabular}

Table 13 Durability test results

\begin{tabular}{llllll}
\hline S. no & Mix type & $\begin{array}{l}\text { dry weight in grams } \\
\text { (W1) }\end{array}$ & $\begin{array}{l}\text { wet weight in } \\
\text { (W2) }\end{array}$ & grams & \% water absorption \\
\hline 1 & C.C & 8439.84 & 8466 & 0.31 \\
2 & M1A & 8661.75 & 8699 & 0.43 \\
3 & M2B & 8629 & 8673.5 & 0.515 \\
4 & M3C & 8618.6 & 8679 & 0.7 \\
5 & M4D & 8745.8 & 8821.5 & 0.86 \\
\hline
\end{tabular}




\section{Conclusion}

As the \% replacement of IOT and GGBFS increase in the concrete mix, workability reduces. This is due to IOT which absorbs more water. When superplasticizer was added at different dosages for all replacement levels, it gave good workability. The mix with $20 \%$ IOT and 5\% GGBFS gave more compressive, split tensile and flexural strength than the conventional mix. The mix with $10 \%$ IOT and 5\% GGBFS has achieved target compression strength but was less than the conventional mix. In the durability test, the rate of water absorption increases as the replacement level increase. The optimum replacement to be taken for having good strength properties is at $20 \%$ IOT and $10 \%$ GGBFS in the concrete mix.

With the addition of different admixtures, changing w/c ratio, mix design, using pre-treatment methods further research can be made. Keeping the replacement of $20 \%$ IOT constant, the GGBFS \% replacement can be increased further to study properties of concrete. More durability tests can be conducted like chloride penetration tests, carbonation test, and air permeability test.

\section{Acknowledgment}

None.

\section{Conflicts of interest}

The authors have no conflicts of interest to declare.

\section{References}

[1] Navale H, Nirmal S, Gund P. Effect on compressive strength and tensile strength of cement concrete road pavements due to use of IOT as a replacement to fine aggregate. International Research Journal of Engineering and Technology. 2017; 4(11):1140-3.

[2] Kuranchie FA. Characterisation and applications of iron ore tailings in building and construction projects. 2015.

[3] Suresh D, Nagaraju K. Ground granulated blast slag (GGBS) in concrete-a review. IOSR Journal of Mechanical and Civil Engineering. 2015; 12(4):76-82.

[4] Kumar BS, Suhas R, Shet SU, Srishaila JM. Utilization of iron ore tailings as replacement to fine aggregates in cement concrete pavements. International Journal of Research in Engineering and Technology. 2014; 3(7):369-76.
[5] Kumar P, Ananthayya, Kumar V. Effect of replacing sand by iron ore tailings on the compressive strength of concrete and flexural strength of reinforced concrete beams. International Journal of Engineering Research \& Technology. 2014; 3(7):1374-6.

[6] Sellakkannu N, Roshini P. Experimental investigation on partial replacement of cement by GGBS. International Journal for Research in Applied Science \& Engineering Technology. 2017; 5(10):1560-5.

[7] Naqash J A, Shaistakanni, Jeelani Z. Effects of super plasticizers on structural properties of concrete. International Journal of Civil Engineering and Concrete Structures. 2016; 1(3):67-71.

[8] Gaur AS, Kumar S. Effect of partial replacement of cement by ground-granulated blast-furnace slag and fine aggregate by marble slurry on properties of concrete. American Journal of Engineering Research. 2017; 6(1):28-31.

[9] Sridevi G, Madhusudhan L, Reddy VM, Phaneendra C, Prajwala G. Studies on strength properties of concrete with partial replacement of cement by GGBS. International Journal of Scientific \& Engineering Research. 2016; 7(11):946-9.

[10] Kaviya BR, Rajkumar AP, Ramakrishnan S, Subash S. Study on partial replacement of cement by ground granulated blast furnace slag. International Journal of Pure and Applied Mathematics. 2017; 116(13):411-6.

[11] IS 12269:1987 codebook conforming to 53-grade cement.

[12] IS 2386 (part-2) codebook for tests on fine aggregate.

[13] IS 2386 (part-3) codebook for tests on coarse aggregate.

[14] IS 456: 2000 codebook for the reference of mix design.

[15] IS 10262 codebook for concrete mix design.

[16] IS 516-1959 Indian standard code of practice methods of test for strength of concrete.

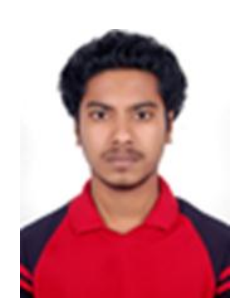

Ravikiran Kattoli was born in 1994. He received his Bachelor Degree in the Department of Civil Engineering, PDA college Gulbarga in 2016. At present, he is pursuing his Master Degree in Construction Technology, VTU CPGS Gulbarga.

Email: ravi.sk132@gmail.com 